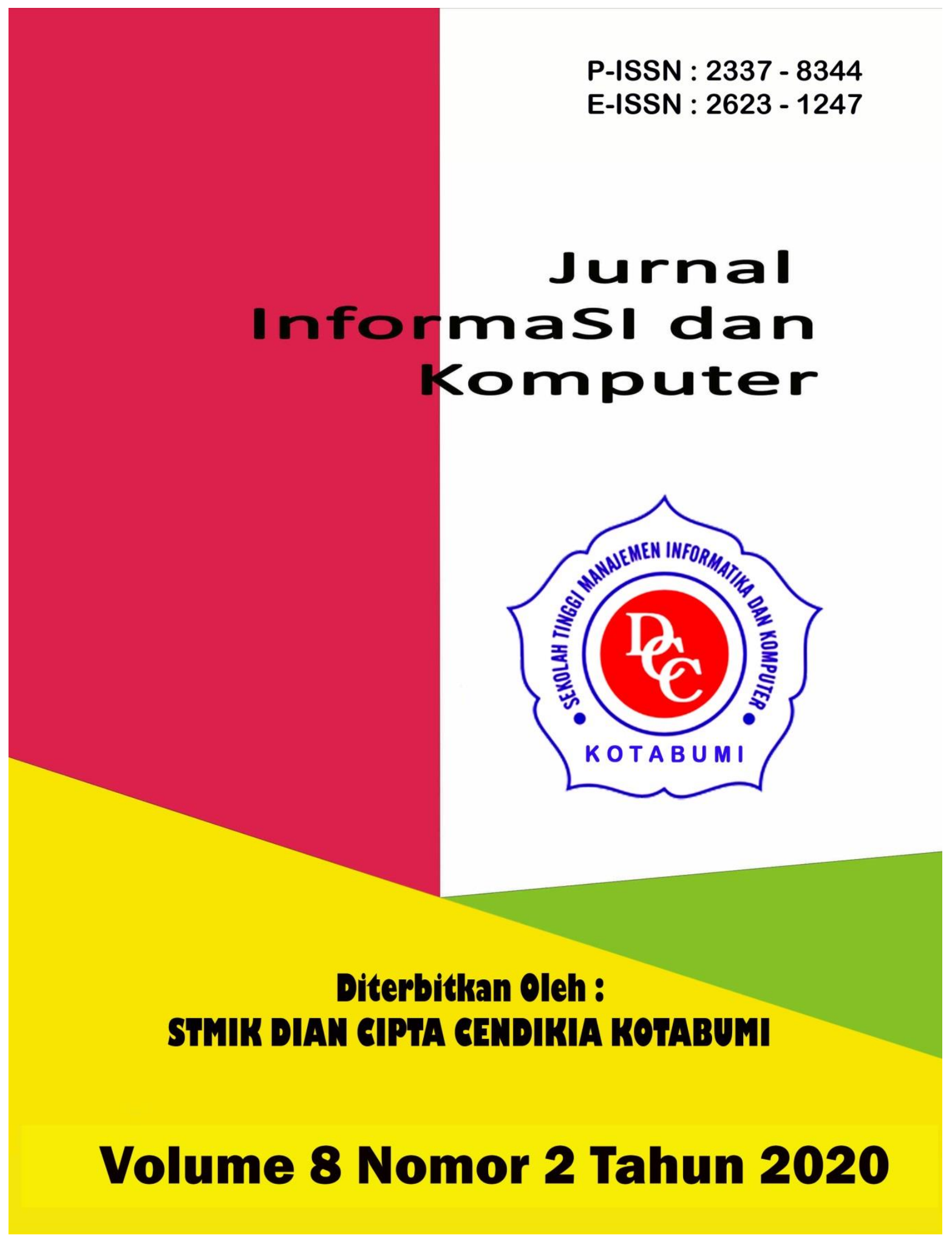




\section{Penerbit:}

\section{STMIK DIAN CIPTA CENDIKIA KOTABUMI}

Bekerjasama dengan LPPM STMIK DCC Kotabumi

Hak atas naskah/tulisan tetap berada pada penulis, isi diluar tanggung jawab

Penerbit dan Dewan Penyunting

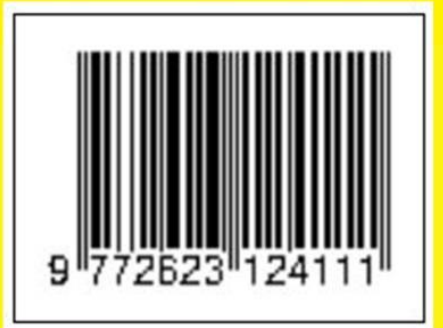

STM IK Dian Cipta Cendikia Kotabumi 


\section{PENGANTAR REDAKSI}

Puji syukur dipanjatkan kehadirat Tuhan Yang Maha Esa, atas karunia dan limpahan rahmatNYA jualah Jurnal Informatika dan komputer (InfoKom) STMIK Dian Cipta Cendikia Kotabumi ini dapat terwujud.Jurnal Informatika dan Komputer (InfoKom) yang terbit dua (2) kali dalam setahun ini merupakan suatu wadah untuk penyebar luasan hasil-hasil penelitian, studi pustaka, karya ilmiah yangberkaitan dengan Informatika dan Komputer khususnya bagi dosen-dosen STMIK Dian Cipta Cendikia Kotabumi serta umumnya para cendikiawan, praktisi, peneliti ilmu Informatika dan Komputer.

Harapan, dengan diterbitkannya Jurnal Informatika dan Komputer (InfoKom) ini sebagai salah satu bentuk sumbangan pemikiran dalam pengembangan ilmu informatika dan komputer yang berkaitan dengan kajian-kajian di bidang tekhnologi Informatik, Komunikasi Data dan Jaringan Komputer, perancangan dan Rekayasa Perangkat Lunak, serta ilmu-ilmu yang terkait dengan bidang Informatika dan Komputer lainnya.

Berkenaan dengan harapan tersebut, kepada para peneliti, dosen dan praktisi yang memiliki hasilhasil penelitian, kajian pustaka, karya ilmiah dalam bidang tersebut diatas, dengan bangga redaksi Jurnal Informatika dan Komputer (JIK) menerima naskah ringkasan untuk dimuat pada jurnal Informatika dan Komputer (InfoKom) STMIK Dian Cipta Cendikia Kotabumi dengan berpedoman pada penulisan naskah jurnal sebagaimana dilampirkan pada halaman belakang (Bagian kulit dalam) buku jurnal ini.

Mutu dari suatu jurnal ilmiah tidak hanya ditentukan oleh para pengelolanya saja, tetapi para penulis dan pembaca jualah yang mempunyai peranan besar dalam meningkatkan mutu jurnal Informatika dan Komputer ini. Merujuk pada realita ini kamu sangat mengharapkan peran aktif dari peneliti untuk bersama-sama menjaga dan memelihara keberlangsungan dari jurnal Informatika dan Komputer STMIK Dian Cipta Cendikia Kotabumi ini. Yang juga tidak kalah pentingnya dari partisipasi tersebut diatas, adalah saran dan kritik yang membangun dari pembaca yang budiman agar kiranya dapat disampaikan langsung kepada redaksi JIK. Saran dan kritik yang membangun akan dijadikan masukan dan pertimbangan yang sangat berarti guna peningkatan mutu dan kualitas Jurnal Informatika dan Komputer STMIK Dian Cipta Cendikia Kotabumi.

Tak lupa diucapkan terima kasih yang tak terhingga atas perhatian dan kerjasama dari semua pihak yang tak dapat disebutkan satu persatu hingga dapat diterbitkan nya Jurnal Informatika dan Komputer (InfoKom) STMIK Dian Cipta Cendikia Kotabumi. Semoga apa yang telah diperbuat untuk kebaikan akan menjadi amal ibadah, amin.

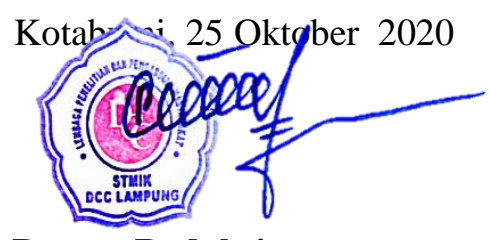

Dewan Redaksi 


\section{JURNAL INFORMASI DAN KOMPUTER}

Volume 8 Nomor 2 Oktober 2020

Jurnal Informasi dan Komputer merupakan Sarana informasi ilmu pengetahuan, Tekhnologi dan Komunikasi yang berupa hasil penelitian, tulisan ilmiah, Ataupun studi pustaka. Jurnal ini terbit dua kali setahun pada bulan April dan Oktober. Berisi hasil penelitian ilmiah di bidang informatika yang bertujuan untuk menghubungkan adanya kesenjangan antar kemajuan teknologi dan hasil penelitian. Jurnal ini di terbitkan pertama kali pada tahun 2013.

Penanggung Jawab:

Ketua STMIK Dian Cipta Cendikia Kotabumi

\section{Pembina:}

Ketua STMIK Dian Cipta Cendikia Kotabumi Ketua Lembaga Penelitian STMIK Dian

Cipta Cendikia Kotabumi

\section{Pimpinan Redaksi}

Dwi Marisa Efendi,.S.Kom.,M.T.I

\section{Redaksi pelaksana}

Rustam,.S.Kom,.M.Ti (STMIK Dian Cipta

Cendikia Kotabumi)

Nurmayanti M.Kom (STMIK Dian Cipta

Cendikia Kotabumi)

Sukatmi,.S.Kom., M.Kom (AMIK DCC

Bandar Lampung)

Sampurna Dadi Riskiono,M.Kom

(Universitas Teknokrat Indonesia)

Ifo Wahyu Pratama,S.Kom.,M.Ti(AMIK

MASTER Lampung)

\section{Mitra Bestari}

Merri Parida.,M.Kom (STMIK Dian Cipta

Cendikia Kotabumi)

Amarudin,S.Kom.,M.Eng (Universitas

Teknokrat Indonesia)

Didi Susianto.,S.T.,M.Kom (AMIK DCC

Bandar Lampung)

Alhibarsyah.,S.T.,M.Kom (Stmik Tunas

Bangsa Bandar Lampung)

Kemal Farouq Mauladi .,S.Kom.,M.Kom

(Universitas Islam Lamongan)

Agus Setiawan S.Pd.,M.Eng (Universitas

Muhammadiyah Lamongan)

Ferrly Ardhy, S.Kom., M.Ti (Universitas

Aisyah Pringsewu)

Penerbit : STMIK Dian Cipta Cendikia

Kotabumi Bekerja Sama Dengan LPPM

STMIK Dian Cipta Cendikia Kotabumi.

\section{Alamat Redaksi/Penerbit:}

Jl. Negara No. 3 Candimas Kotabumi

Lampung Utara

No Telpon/Fax 072423003

Email : Ippm-stmik@dcc.ac.id 


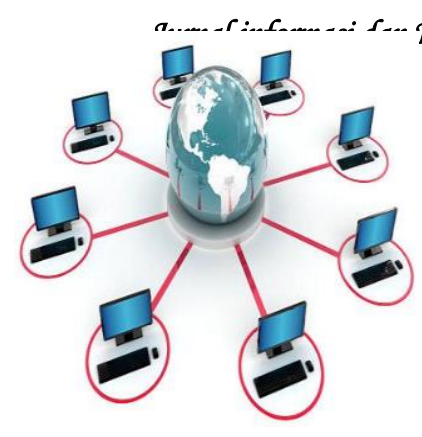

\section{JURNAL INFORMASI DAN KOMPUTER VOL. 8 NO. 2 THN. 2020}

\section{DAFTAR ISI}

\section{Halaman}

Sistem Pakar Identifikasi Penyakit Kelapa Sawit Dengan Metode Fuzzy Mamdani Dan Certainty Factor Studi Kasus : "Kelompok Tani Desa Banjar Kertarahayu" Asep Afandi, Rustam, (Universitas Gunadarma, IIB Darma Jaya). $01-12$

Rancang Bangun Sistem Informasi Pemetaan Toko Oleh-Oleh Dan Souvenir Khas Lampung Dikota Bandar Lampung Berbasis Android Yuli Syafitri, Muhammad Rizal (IIB Darma Jaya Bandar Lampung, AMIK DCC Bandar Lampung)

Implementasi Data Mining Menggunakan Multi Regresi Untuk Memprediksi Rerata Kedatangan Masyarakat, Sigit Mintoro, Dwi marisa Efendi, Riski Oskar Pratama,

(IIB Darma Jaya, STMIK Dian Cipta Cendikia Kotabumi)

25-30

Audit Sistem Informasi Pembayaran Spp Menggunakan It-Il Version 3

Ferly Ardhy, Ardiana Safitri

(IIB Darma Jaya,STMIK Dian Cipta Cendikia Kotabumi) $31-40$

Penerapan Metode Extreme Programming Smartschool Pada SMK Nusantara 1 Kotabumi

Merri Parida, Ahmad Basori Ali

(AMIKOM Yogyakarta, STMIK Dian Cipta Cendikia Kotabumi)

41-50

Penerapan Metode Extreme Programming Pada Sistem Informasi Layanan Perpustakaan SMP Negeri 3 Negara Batin Berbasis Web Mobile

Nurmayanti, Yoga Iman Wijaya

(AMIKOM Yogyakarta, STMIK Dian Cipta Cendikia Kotabumi) $51-58$

Analisis Celah Keamanan Jaringan Dan Server Menggunakan Snort Intrusion Detection System

Aliy Hafiz,Triandi Kurniawan, Nuari Anisa Sivi, Fathurrahman Kurniawan Ikhsan, Panji Andhika Pratomo

(AMIK Dian Cipta Cendikia, UNU Lampung, UMITRA Indonesia, STMIK Pringsewu) $59-66$

Sistem Informasi Data Penjualan Dan Stok Barang Di Toko Rudi Etalase Berbasis Web

Ngajiyanto, Rima Mawarni, Sigit Mintoro, Fachri Pawiga

(AMIKOM Yogyakarta, STMIK Eresha, IIB Darma Jaya, STMIK Dian Cipta Cendikia Kotabumi ) .... $67-74$

Penerapan Data Mining Untuk Prediksi Penjualan Produk Triplek Pada Pt Puncak Menara Hijau Mas Rustam, Sidik Rahmatullah, Supriyato, Sri Wahyuni

(IIB Darma Jaya, AMIKOM Yogyakarta, IIB Darma Jaya, STMIK DCC Kotabumi) ..... $75-86$ 
Sistem Informasi Penjualan Helm Secara Online Pada Toko Dewi Di Kotaagung Kabupaten Tanggamus (Studi Kasus Toko Dewi Kotaagung) Rima Mawarni, Dewi Triyanti, Dewi Zaurati, S.Kom (STMIK Eresha, IIB Darma Jaya, AMIK Dian Cipta Cendikia Pringsewu). $87-92$ 


\title{
IMPLEMENTASI DATA MINING MENGGUNAKAN MULTI REGRESI UNTUK MEMPREDIKSI RERATA KEDATANGAN MASYARAKAT
}

\author{
Sigit Mintoro ${ }^{1}$, Dwi marisa Efendi ${ }^{2}$, Ferly Ardhy ${ }^{3}$, Riski Oskar Pratama ${ }^{4}$ \\ STMIK Dian Cipta Cendikia Kotabumi ${ }^{1234}$ \\ Jl.Negara No.03 Candimas Kotabumi \\ E-mail : sigit@dcc.ac.id, dwimarisa@dcc.ac.id, Ferly@dcc.ac.id², riski@gmail.com³
}

\begin{abstract}
ABSTRAK
Dalam penelitian,ini dilakukan analisa dengan menggunakan metode regresi linier,berganda untuk memprediksi,angka kedatangan masyarakat pada kantor disduk capil lampung utara dengan menggunakan Microsoft,Excel 2010 dan aplikasi Rapid miner,,dalam penelitian ini terdapat variabel independen, bebas dan variable independen,terikat yaitu variable independen,bebas yaitu :stok blangko, Operator, dan waktu pengerjaan. Sedangkan variable independen,terikat yaitu : jumalah masyarakat yang datang. Prediksi angka kedatangan masyarakat pada kantor disduk capil dengan mengabil sampel x1 $=795$ keping orang , $\mathrm{x} 2=3$ orang , $\mathrm{x} 3=7 \mathrm{jam}$, dan $\mathrm{Y}=296$ orang menunjukan hasil prediksi $-92,2484452$ menujukan nilai eror data 0,548 untuk angka kedatangan masyarakat
\end{abstract}

Kata kunci : regresi, Rapid miner, Prediksi, masyarakat, analisa.

\section{ABSTRACTS}

This research uses multiple linear regression methods. research is useful to predicate the average number of people's arrival. this research uses Microsoft Excel 2010 and Rapid miner applications. The variables used are independent variables, free: stock blangko, operator, and working time. predicted to use sample xI $=795, x 2=3$ people, $x 3=7$ hours , and $y=296$ people. Prediction result is -92.2484452 , error value data 0.548 and 0.548 for public arrivals.

Keywords: regression, Rapid miner, Prediction, community, analysis.

\section{PENDAhUluAN}

Dinas kependudukan,dan pencatatan sipil merupakan instansi pelayanan penerbitan dokumen kependudukan seperti KK,KTP, AktaAkta. Oleh karna itu instansi ini selalu ramai dikunjungi masyarakat, untuk mengurus dokumen kependudukan. Setiap hari instansi ini dikunjungi Oleh,masyarakat dengan jumlah berbeda, beda. Sering terjadinya, kekurangan, stok blangko sehingga menyebabkan masyarakat menjadi terhamabat di saat pengurusan dokumen, kependudukan, dan harus menunggu, sampai, tersedianya kembali blangko tersebut.

Membeludaknya antrian masyarakat yang, di akibatkan, stok blangko yang tidak stabil. Belum ditemukan, metode untuk memprediksi, angka kedatangan masyarakat.
Adapun tujuan dari penelitian adalah:

Untuk mengetahui, dan menganalisis angka kedatangan, masyarakat perhari pada kantor Disduk Capil Lampung Utara dengan menggunakan metode regresi. Penulis dapat memberikan referensi, dalam mengimplementasikan, Rapidminer dalam, menentukan alokasi jumlah blangko pada kantor Disduk Capil Lampung Utara.

Prediksi adalah suatu, proses memperkirakan secara sistematis tentang sesuatu yang paling mungkin terjadi di masa depan berdasarkan, informasi masa lalu dan sekarang yang dimiliki, agar kesalahannya (selisih antara sesuatu yang terjadi dengan hasil perkiraan) dapat diperkecil[1] Analisis regresi, merupakan metode 
sederhana untuk melakukan, investigasi, tentang hubungan fungsional, di antara beberapa variable[2] penerapan data mining juga di implementasikan dengan metode yang berbeda yaitu Penerapan Algoritma, C5.0 untuk mengetahui permintaan produk kartu, perdana internet pada Vidha Ponsel.[3]

\section{METODE PENELITIAN}

Pada tahapan ini penulis mengelompokkan datadata yang didapat .Pengelompokkan dimulai dengan menentukan variable independent dan ariabledependen. Adapun variable-variable tersebut terdiri atas sebagai berikut [1].

1. Variable bebas (variable independen) : variable ini menjelaskan dan mempengaruhi variable lain yaitu : stok blangko $\left(\mathrm{X}_{1}\right)$ ,operator $\left(\mathrm{X}_{2}\right)$,waktu pengerjaan $\left(\mathrm{X}_{3}\right)$,

2. Variabel Terikat (variable dependen) : variable dipengaruhi oleh variable independent yaitu jumlah masyarakat yang mendaftar (Y).

Berikut adalah tahapan dalam pengolahan data regresi linear berganda :

1. Menyiapkan data prediksi menggunakan 1 variabel terikat (y) dan 3 variabel bebas.

2. variabel terikat : $Y=$ Jumlah masyarakat yang mendaftar.

3. variabel bebas : $\mathrm{x} 1=$ stok blangko, $\mathrm{x} 2=$ operator , $\mathrm{x} 3=$ waktu pengerjaan,

4. Kemudian mulai melakukan perhitungan untuk memangkatkan dua, X1, X2, $\mathrm{X} 3, \mathrm{X} 4$ dan $\mathrm{Y}$.

5. Memangkatkan dua variable bebas dan terikat.(X12, X22, X32)

6. Kemudian mengalikan antara variable bebas dengan variable terikat (X1.Y, X2.Y, X3.Y,)

7. Kemudian menghitung dengan mengalikan antara variable bebas dengan

8. variable bebas lainnya (X1.X2, X1.X3, X2.X1 ,X2.X3., X3.X1, X3.X2,)

9. Rumus persamaan regresi linear berganda 3 variabel yaitu : a. $Y=a+b 1 X 1+b 2 X 2+\mathrm{b} 3 \mathrm{X} 3$

Keterangan:

$\mathrm{Y}=$ Jumlah masyarakat yang daftar $\mathrm{a}=$ Konstanta

$\mathrm{X} 1$ = blangko

$b 1=$ Koefisien 1

$\mathrm{X} 2$ = operator

$b 2=$ Koefisien 2

X3 = waktu pengerjaan

b3= Koefisien 3

10. Kemudian tahapan yang terakhir adalah mencari nilai eror dari data yang telah di dapat dari perhitungan sebelumnya.

Rumus $=((\mathrm{Yi}+\gamma \mathrm{i})-\mathrm{n}) / \mathrm{n} \times 100 \%$

Keterangan:

Yi = Data awal sebenarnya (Data

sebenarnya)

yi = Data akhir (Data hasil estimasi)

$\mathrm{n}=$ Jumlah data prediksi

\section{HASIL DAN PEMBAHASAN}

Berikut proses perhitungan angka kedatangan prediksi kedatangan (Studi Kasus Kantor Disdukcapil Lampung Utara) dengan Metode regresi linier berganda dengan menggunaka Microsoft excel 2010. Dengan informasi dari data pembelajaran tahun 2018 s/d 2020 sebagai berikut

\section{Prediksi angka kedatangan}

a) Jumlah masyarakat yang datang tertinggi= 1184 dan kedatangan terendah $=0$ masyarakat perhari

b) Jumlah stok blangko paling banyak $=7758$ dan stok blangko paling sedikit $=0$

c) Jumlah operator terbanyak $=3$ dan operator paling sedikit $=0$

d) Waktu pengerjaan paling lama $=12$ jam dan waktu pengerjaan paling sedikit $=0$ jamkuantitatif. Hasil percobaan sebaiknya ditampilkan dalam berupa grafik ataupun tabel.

yaitu prediksi angka kedatangan yang akan dijadikan label 


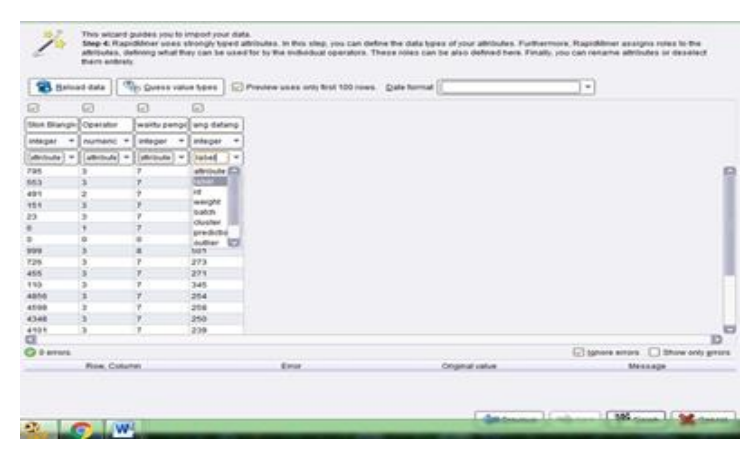

Gamabr 1tampilan fatribute data uji menjadi tipe data

Selanjutnya memilih metode yaitu metode regresi linier. Kemudian hubungkan antara port-port linear regression, read excel 2 dengan apply model dan hubungkan juga ke result untuk melihat hasil prediksi dari data yang sudah kita buat

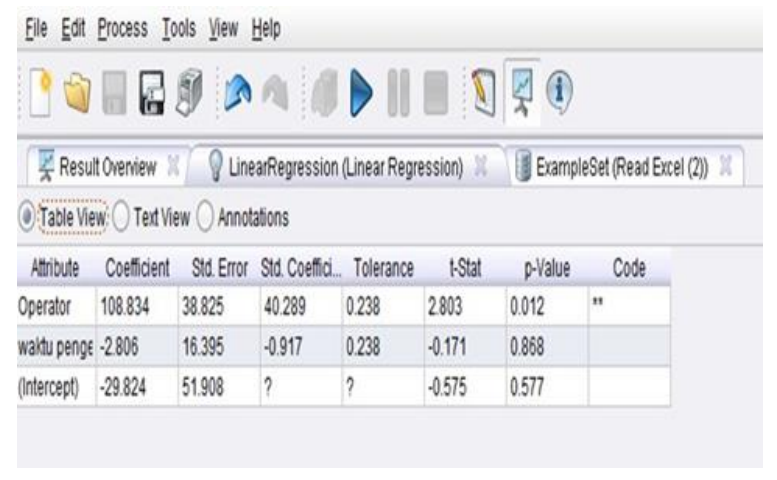

Gambar 2 . Tampilan dari hasil Nilai Error.

Berdasarkan hasil penelitian diperoleh dari hasil prediksi pada variabel terhadap jumlah kedatangan masyarakat mengacu pada tahun 2018 sampai 2020 dengan di lakukan 451 kali prediksi menunjukan bahwa variabel yang digunakan system berpengaruh terhadap system prediksi angka kedatangan masyarakat. pada perhitungan mengguankan metode regresi linier dalam memprediksi angka kedatangan masyarakat dapat digunakan kantor disdukcapil dalam mengambil sebuah keputusan dengan nilai prediksi yang mendekati data hasil olahan sebagai data pembelajaran pada prediksi angka kedatangan masyarakat pada kantor disdukcapil dengan mengabil sampel $\mathrm{x} 1=795$ keping orang , x2=3 orang, x3=7 jam, dan $Y=296$ orangmenunjukan hasil prediksi $-92,2484452$ menujukan nilai eror data 0,548 untuk angka kedatangan masyarakat.pada kantor disduk capil lampung utara

\section{KESIMPULAN}

Dari hasil yang telah dilakukan dapat disimpulkan bahwa :

prediksi angka kedatangan masyarakat pada kantor disdukcapil dengan mengambil sampel $\mathrm{x} 1$ =795 keping belangko, x2=3 orang, x3=7 jam , dan $\mathrm{Y}=296$ orangmenunjukan hasil prediksi 92,2484452 menunjukan nilai eror data 0,548 untuk angka kedatangan masyarakat.pada kantor disdukcapil lampung utara.dapat di terima sebagai data pembelajaran untuk prediksi kedepanya

[1] Hutabarat, Carlis. "Penerapan Data Mining, Untuk Memprediksi Permintaan Produk, Kartu Perdana Internet Menggunakan, Algoritma C5. 0 (Studi Kasus: Vidha Ponsel)." Pelita Informatika: Informasi dan Informatika 6.4 (2018): 168-173.

[2] Sembel, Tesyalom, Ronny Gosal, and Sofia Pangemanan. "Partisipasi Masyarakat Dalam Pembangunan Desa (Studi di Desa Sinsingon Barat Kecamatan Passi Timur Kabupaten Bolaang Mongondow)." JURNAL EKSEKUTIF 1.1 (2017).

[3] Sulistio, Andreas. "Pengaruh Promotion Mix Terhadap Brand Awareness Pt Hm Sampoerna Tbk Melalui Produk Terbaru Sampoerna A Platinum." Jurnal Strategi Pemasaran 5.2 (2018).

[4] Negara, Dengan Menganalisis Tingkat Dystopia Suatu. "Prediksi Tingkat Kehidupan Masyarakat Di Mancanegara."

[5] Syahra, Yohanni, Ismawardi Santoso, And Rini Kustini. "Implementasi Data Mining Untuk Prediksi Angka Kelahiran Bayi Pada Desa Sibolangit Menggunakan Multi Regresi." Seminar Nasional Sains Dan Teknologi Informasi (Sensasi). Vol. 2. No. 1. 2019.

[6] Gaol, Indah Lestari Lumban, Sinar Sinurat, 
And Edward Robinson Siagian.

"Implementasi Data Mining

Dengan Metode Regresi Linear

Berganda Untuk Memprediksi Data

Persediaan Buku Pada Pt.

Yudhistira Ghalia Indonesia Area

Sumatera Utara." Komik

(Konferensi Nasional Teknologi

Informasi Dan Komputer) 3.1 (2019).

[7] Gusman, Aggy Pramana. "Penerapan Fuzzy Time Series Dalam Menganalisa Peramalan Kedatangan Wisatawan Setelah Diterapkan Konsep Halal Tourism Sumatera Barat." Seminar Nasional Teknologi Informasi Komunikasi Dan Industri. 2018.

[8] Wulandari, Ni Luh Putu, Et Al. "Prediksi Jumlah Pelanggan Dan Persediaan Barang Menggunakan Metode Regresi Linier Berganda Pada Bali Orchid." Josinfo: Jurnal Online Sistem Informasi 1.1 (2015).

[9] Budiman, Irwan, And Artesya Nanda Akhlakulkarimah. "Aplikasi Data Mining Menggunakan Multiple Linear Regression Untuk Pengenalan Pola Curah Hujan." Klik-Kumpulan Jurnal Ilmu Komputer 2.1 (2016): 34-33.

[10] Gunawan, Rudi. "Implementasi Data Mining Untuk Memprediksi Prestasi Siswa Berdasarkan Status Sosial Dan Kedisiplinan Pada Smk Bayu Pertiwi Menggunakan Metode Regresi Linier Berganda." Jurnal Saintikom (Jurnal Sains Manajemen Informatika Dan Komputer) 17.2 (2018): 175-183

[11] Fikri, Ali. "Penerapan Data Mining Untuk Mengetahui Tingkat Kekuatan Beton Yang Dihasilkan Dengan Metode Estimasi Menggunakan Linear Regression." Universitas Dian Nuswantoro, Semarang (2013).

[12] Nikmatun, Inna Alvi, And Indra Waspada. "Implementasi Data Mining Untuk
Klasifikasi Masa Studi Mahasiswa Menggunakan Algoritma K-Nearest Neighbor." Simetris: Jurnal Teknik Mesin, Elektro Dan Ilmu Komputer 10.2 (2019): 421-432.

[13] Yusuf, Ahmad, Hari Ginardi, And Isye Arieshanti. "Pengembangan Perangkat Lunak Prediktor Nilai Mahasiswa Menggunakan Metode Spectral Clustering Dan Bagging Regresi Linier." Jurnal Teknik Its 1.1 (2012): A246-A250.

[14] Sulthan, Nafis, Nurafni Eltivia, And Nur Indah Riwajanti. "Implementasi Metode Exponential Smoothing Untuk Peramalan Kedatangan Wisatawan Mancanegara Pada Pulau Bali." Media Mahardhika 18.2 (2020): 171-178.

[15] Supriatna, Agus, Et Al. "Prediksi Wisatawan Mancanegara Ke Jawa Barat Melalui

[16] Pintu Masuk Bandara Husein Sastranegara Dan Pelabuhan Muarajati Menggunakan Metode Sarima." Prosiding Industrial Research Workshop And National Seminar. Vol. 8. 2017.

[17] Sovia, Rini, Musli Yanto, And Putri Melati. "Prediksi Jumlah Kunjungan Wisata Mancanegara Dengan Algoritma Backpropagation." Jurnal Media Informatika Budidarma 4.2 (2020): 355-36

[18] Syafitri, Yuli. "Membangun Sistem Informasi Persediaan Barang Dagang." Jurnal Cendikia 15.2 Oktober (2017): 26-32.

[19] Efendi, Dwi Marisa, and Ferly Ardhy. "Penerapan Data Mining Untuk Peramalan Penjualan Obat dengan Menggunakan Single Exponential Smoothing di Apotek Hamzah Farma." Prosiding Seminar Nasional Darmajaya. Vol. 1. No. 1. 2018.

[20] Rahmatullah, Sidik, Mukrim Mukrim, And 
Monica Nindy Pramitha. "Data Mining Untuk Menentukan Produk Terlaris Menggunakan Metode
Naive Bayes." Jurnal Informasi Dan

Komputer 7.2 (2019):

57 